\title{
A Study on Cultural Factors in Sino-US Business Negotiation
}

\author{
YU Ting \\ Ningbo Dahongying University, Ningbo, China
}

\begin{abstract}
Since China joined World Trade Organization officially, business activities between China and the United States are increasing rapidly. However, due to the huge cultural differences between China and the United States, people of the two countries have so many differences in thinking, life style, world outlook, and so on. In the course of business negotiations in the Sino-US negotiations, communication barriers and unnecessary misunderstanding may occur. This paper analyses the major cultural differences in Sino-US business negotiation and comes up with some effective negotiating strategies for Chinese business negotiators.
\end{abstract}

Keywords: culture, negotiation, Sino-US

\section{Introduction}

With the development of the process of globalization, the contact and cooperation between the countries in the political, economic, cultural, and technological fields have become more and more strengthened. China has attracted the world's attention with its rapid economic growth and huge market potential. More and more foreigners began to do business in China, so cross-cultural business negotiations with the international economic and trade exchanges have become more frequent.

As the biggest developed country, the United States has a close trade relationship with China. Conducting a successful business negotiation means a lot, not only bring benefits to both countries, but also to the economic development of the whole world.

\section{Major Cultural Differences in Sino-US Business Negotiations}

Culture is complex and the earliest definition was given by the British anthropologist Edward Tylor in his book Primitive Culture: "culture is a complex whole which includes knowledge, belief, art, morals, law, custom, and other capabilities acquired by man as a member of society" (Tylor, 1997, p. 11). Cultural factors have always been one of the most active factors in the process of intercultural communication in business negotiation. Chinese culture is quite different from the United States in the aspects of belief, value, life style, world outlook, and so on.

\section{Main Origins of Chinese Culture and American Culture}

Main origins of Chinese culture and American culture are totally different. The Chinese value of group loyalty, respect for the level, and pursuit of harmony are difficult for Americans to understand. And more importantly, Americans think Chinese concerned too much with "face" stuff, such as saving face giving face and losing face. So to Americans, they often regarded as land of inscrutable. Many typical Chinese behaviors are shaped by a unique set of core values that are different from the West. Confucianism is regarded as a 
religion by some Western scholars because of its profound impact on the Chinese culture. During the long history of development in the United States, Christianity has evolved into many different schools and offshoots. And the most popular one in America may be Puritanism. Puritan valued in early America and then it went deep into American culture and shaped the entrepreneurial spirit of the Americans.

\section{Value System}

The most obvious cultural difference in Sino-US business negotiations is value system. Value system not only affects the way how people understand the problems, but also gives people a strong emotional impact. In different cultures, value system can make a big difference. Chinese negotiators pay special attention to the establishment of friendly business relations between two sides. Negotiations are seen as a symbol of friendship and cooperation, signing the contract represents the beginning of a long-term mutually beneficial cooperation. On the contrary, American negotiators regard the economic benefits as the purpose of business negotiations. They pay special attention to the contract, discuss the terms of the contract seriously, and pay special attention to the compensation clause and the applicable law of the contract.

\section{Time Perception}

China and the United States negotiators also have totally different views of time perception. Time-related misunderstanding is an old topic which has drawn much attention of negotiators and scholars in international business negotiations. This kind of misunderstanding caused many cross-cultural time related problem. Americans think highly of time, time is money and wealth for them, so they will maximize the use of time to achieve the maximum benefit. Americans usually want to reach an agreement within a relatively short period of time. They used to carry out complex negotiations in accordance with the order, from one stage to another stage, such as in order to solve the price, packaging, delivery, and other issues. But in China, the view of time is cyclical. So Chinese will consider the problem in the long term. They usually pay more attention to cooperation and the length of time to complete the negotiations will not be very strict restrictions. They usually do not want to separate the whole negotiation into a separate issue to be discussed separately. It is normal for Chinese to discuss several issues at the same time, but Americans cannot understand.

\section{Thinking Pattern}

Thinking pattern refers to a form of reasoning and problem solving methods which is different from culture to culture. A logical and reasonable way of thinking pattern in one culture may be considered as illogical and unreasonable in another. As for Chinese and American thinking patterns are concerned, Chinese thinking pattern is more intuitive and effective. While American thinking pattern is more logical and rational. Chinese people usually start from general observations, and then they will consider the specific plots in detail. In contrast, Americans believe in the existence of objective truth should be found one by one. So in general, Chinese people's mode of thinking is deductive while the American thinking pattern is inductive.

\section{Effective Negotiating Strategies for Chinese Business Negotiators From the Perspective of Cultural Awareness}

\section{Using Correct Greetings}

Greeting is the process of negotiation process of mutual understanding between the two sides. The negotiator chooses the means of communication used in the official negotiation based on the information in the greeting. So using the correct greetings is particularly important. 
American culture emphasizes things and people will not be confused; this is caused by the American culture. They are mainly interested in topic about negotiations. Therefore, American businessmen will soon work on the talks. On the contrary, Chinese cultures value relationships tend to spend a lot of time and cost to do a lot of establishing good relations, so Chinese will focus on the establishment of a harmonious relationship before the negotiation starts, and then negotiate.

Take this for example. Before the negotiation, Americans will always say "Beautiful day, isn't it? It looks like it is going to snow". As greeting, they often talk about weather or travel or something that is unrelated to the business.

The Americans say some greetings before the negotiations only for the friendly or polite, and most of them end in 10 minutes, then they will quickly enter the stage of negotiation. So Chinese negotiators should not only use correct greetings but also pay attention to time control before the negotiation.

\section{Respecting and Taking Each Other's Position}

A clever negotiator in the negotiations, even if the purpose is to promote their products, they should avoid saying my or we, but should take each other's position and the attitude of the other. Change self-attitude into other-attitude. Americans attach great importance to their own interests, so Chinese negotiators should pay more attention to respect their position. Specifically speaking, Chinese business negotiators should reduce the expression of selfish opinion in the negotiations.

Take these two sentences for example:

A: We have a good selection of winter clothes at China Autumn Export Commodities Fair.

B: You can choose from a very good selection of winter clothes at China Autumn Export Commodities Fair.

In these two statements, statement A is self-centered. On the contrary, statement B is on the other side. Therefore, statement B is much easier for Americans to accept. So in the negotiations, Chinese negotiators should respect and take Americans' position. It will make the negotiation more successful.

\section{Conducting Politeness Strategies}

Politeness plays a positive role in maintaining harmonious interpersonal relationships. The appropriate language influenced by social factors, the degree of politeness language is also restricted by social factors. The principle of politeness emphasizes talking to see the object, pay attention to words and deeds of time and occasion, pay attention to words and deeds, but also pay attention to verbal expression and effect. Chinese people pay more attention to the level of distinction, so the language will also have a level. But Americans believes in freedom and equality, it influence their attitudes towards polite. So the Chinese business negotiators should avoid using the tone of blame.

Take these two sentences for example:

A: You obviously ignored the fact that the sales of my company are improving.

B: You may be pleased to know that the sales of my company are improving.

In these two statements, statement A sounds like blaming other for ignoring the sales are improving. It is impolite. On the contrary, the tone of statement B is more gentle and polite. Therefore, Americans prefer statement B. So in the negotiations, Chinese negotiators should always remember being polite.

\section{Reducing Emotional Confrontation, Expanding Positive Optimism}

In the negotiations, negotiators should reduce their antagonism in the negotiations, reduce the negative pessimistic side of the negotiations, and expand the positive side of optimism. 
Take these two sentences for example. When one side has to delay the date of delivery, how will they express:

A: Because of recent heavy demand of our products, we will not be able to deliver your goods before August 12.

B: Although the recent demand of our products is heavy, we will do our best to deliver your goods by August 12.

As for these two statements, A is complaining about the heavy demand, it will make other feel negative. But in statement B, they try to express a positive emotion. It makes other believe in them and will not feel unpleasant. So for Chinese negotiators, when meet some problems in negotiating process, they should reduce emotional confrontation and expand positive optimism.

\section{Using Humorous Pragmatic Strategies}

In business negotiations, humorous language can make a serious atmosphere becomes acceptable, so that the negotiating atmosphere immediately becomes lively. So negotiators are psychologically satisfied, and then improve the efficiency of negotiations.

For example, when the negotiation is over and one of the negotiators says "I'm of the opinion that our meeting is fruitful. But there is only one point that I feel disappointed (pause). What I feel disappointed is that there is no single issue at all that needs debating between us".

In this situation, the negotiator makes a good use of humorous pragmatic strategies. Let the negotiations end in a relaxed and pleasant atmosphere. The American negotiators prefer the relaxed atmosphere of the negotiations, so the use of humorous pragmatic strategies plays an important role. Therefore, for the Chinese negotiators, using humorous pragmatic strategies is a necessary lesson to learn.

\section{Conclusion}

In a word, the cultural difference is a core idea in the cross-cultural business negotiation. And effects of cultural factors on international business negotiation are the most direct and most extensive. With the arrival of the global economic integration, the economic and trade activities become more and more frequent. The success of the international business negotiations directly affects the results of the trade. If we want to be in an invincible position in business activities, we should thoroughly study the culture of various countries, try to reduce and avoid the negative effects brought by cultural differences. Only understanding the differences between Chinese and American cultures and how it influences the business negotiations can we find the real cause of misunderstanding or conflict with each other, and ultimately to find effective communication channels, grasp the direction and progress of the negotiations.

This paper analyses the major cultural differences in Sino-US business negotiation and comes up some effective negotiating strategies for Chinese business negotiators. Avoid cultural misunderstanding caused by cultural differences, so that negotiations deadlocked. But there are still some shortcomings in this essay, and I will continue to study the cultural differences between China and the United States in the future.

\section{References}

Acuff, F. L. (1993). How to negotiate anything with anyone anywhere around the world. New York: American Management Association.

Bates, D. G., \& Frost, E. L. (1990). Cultural anthropology (3rd ed.). New York: McGraw-Hill. 
Bender, D. L. (1993). American values: Opposing viewpoints. San Diego, CA: Greenhaven Press.

Brislin, R. W. (1993). Understanding culture's influence on behavior. Fort Worth, TX: Harcourt Brace Jovanovich College Publishers.

Fisher, G. (1980). International negotiations: A cross-cultural perspective. Yarmouth, ME: Intercultural Press.

Garrison, T. (1996). International business culture. Huntingdon Cambs: ELM Pub.

Gudykunst, W., \& Kim, Y. Y. (1997). Communicating with strangers: An approach to intercultural communication. New York \& London: McGraw-Hill Companies.

Hall, E. T. (1997). Beyond culture. Garden City, NY: Anchor, Doubleday.

Hofstede, J. (1984). Culture's consequences: International differences in work related values. Beverley Hills, CA: Sage.

Mitchell, C. (2000). International business culture. Shanghai: Shanghai Foreign Language Education Press.

Phatak, A. V., \& Mohammed, M. H. (1996). The dynamics of international business negotiations. Oxford: Business Horizon. 